\title{
Spectrofluorimetric study of dissolved organic matter in River Salaca (Latvia) basin waters
}

\author{
M. Klavins ${ }^{(1)}$, I. Kokorite ${ }^{(1) \star}$, L. Ansone ${ }^{(1)}$, L. Eglite $^{(1)}$, V. Rodinov ${ }^{(1)}$, G. Springe ${ }^{(1)}$ \\ Received December 8, 2010 \\ Revised December 14, 2011 \\ Accepted December 15, 2011
}

\section{ABSTRACT}

Key-words:

$D O M$,

fluorescence

spectra,

Latvia
Dissolved organic matter (DOM) in surface waters influences mineral weathering, nutrient cycling, aggregation of particulate matter and photochemical reactions in waters and aquatic communities. In this study, the effectiveness of UV and fluorescence measurements in distinguishing the origin of DOM and processes within the river basin were analyzed using the River Salaca basin as an example. The basin of River Salaca is characterized by low anthropogenic pressure, however, the water color during the last few decades has increased (an effect known as brownification). As tools to study the composition of dissolved organic substances in waters of the River Salaca and its tributaries the use of UV and fluorescence spectroscopy was evaluated. The use of the fluorescence index (a ratio of the emission intensity at a wavelength of $450 \mathrm{~nm}$ to that at $500 \mathrm{~nm}$ ) allowed us to distinguish sources of aquatic DOM, characterize processes in the water body basin and to follow the changes in organic matter composition. Synchronous scan fluorescence spectrometry was more informative than excitation emission spectra and, provided information on the basic structural features of DOM.

RÉSUMÉ

Étude spectrofluorimétrique de la matière organique dissoute dans le bassin de la rivière Salaca (Lettonie)

Mots-clés : $M O D$, spectres de fluorescence, spectres UV, Lettonie
La matière organique dissoute (MOD) dans les eaux de surface influe l'altération des minéraux, le cycle des nutriments, l'agrégation des particules et des réactions photochimiques dans les eaux et les communautés aquatiques. Dans cette étude, l'efficacité des mesures de fluorescence UV à distinguer l'origine des MOD et des processus au sein du bassin d'une rivière ont été analysés en utilisant la rivière Salaca comme un exemple. Le bassin de la rivière Salaca est caractérisé par une pression anthropique faible, cependant, la couleur de l'eau au cours des dernières décennies a augmenté (un effet connu comme «brownification »). Comme outil pour étudier la composition des substances organiques dissoutes dans les eaux de la rivière Salaca et de ses affluents, l'utilisation de la spectroscopie de fluorescence UV a été évaluée. L'utilisation de l'index de fluorescence (un ratio de I'intensité des émissions à une longueur d'onde de $450 \mathrm{~nm}$ à celle de $500 \mathrm{~nm}$ ) nous a permis de distinguer les sources des MOD aquatiques, de caractériser les processus dans le bassin et de suivre les changements dans la composition de la 
matière organique. La spectrométrie de fluorescence par balayage synchrone a été plus informative que les spectres d'émission d'excitation et a fourni des informations sur les caractéristiques structurelles de base des MOD.

\section{INTRODUCTION}

Organic matter in surface waters has a key role in terrestrial and aquatic biogeochemistry (Neff and Asner, 2001). Dissolved organic matter influences mineral weathering, nutrient cycling, aggregation and photochemical reactions in waters, is a substrate for bacterial growth in aquatic ecosystems, and controls light absorption and the pelagic food chain (Depetris and Kempe, 1993; Pettine et al., 1998; Westerhoff and Anning, 2000; de Lange et al., 2003; Arvola et al., 2004; Evans et al., 2005). Considering this, the flow of DOM is a very important indicator of climate change (Roulet and Moore, 2006). Factors influencing DOC concentrations include climate change, character of hydrological processes and physicogeographic factors as well as human impacts. Recent interest in studies of DOM has been related to the identification of the impacts of climate change (e.g. increase of temperature and mineralization rates, changes of precipitation, atmospheric circulation, etc.) and the roles of human activities (extraction of peat, agricultural activities and land-use changes) on the balance of DOM in surface waters (Vuorenmaa et al., 2006; Evans et al., 2005; Roulet and Moore, 2006; Arvola et al., 2004; Clair et al., 2008).

Of key importance for studies on the flow of organic matter is an understanding of its structural features, as the concept "dissolved organic matter" includes individual organic molecules of varying degradability from highly labile to recalcitrant. The balance between different constituents of the organic matter pool depends on the presence of wetlands in the catchment, intensity of eutrophication, bedrock geology, intensity of agricultural land-use, direct anthropogenic load (also industrial effluents and non-point pollution sources) and other processes within the basin (Gergel et al., 1999).

Classification and characterization of DOM can be carried out using spectrofluorimetry (McKnight et al., 2001; Wu et al., 2007; Baker et al., 2008). Fluorescence spectra can provide information relating to structure, conformation, aromaticity and heterogeneity of DOM (McKnight et al., 2001; Baker et al., 2008). It has been demonstrated that larger molecular weight fractions have a lower fluorescence than smaller molecular weight fractions, however, allochtonous DOM possesses different fluorescence properties than DOM from autochtonous sources (Kelton et al., 2007; McKnight et al., 2001; Baker et al., 2008).

The aim of this study was to assess the effectiveness of fluorescence measurements in distinguishing the origin of DOM and processes within the river basin using the River Salaca basin as an example. The River Salaca basin is characterized by lower anthropogenic pressure compared to other large and medium sized river basins in Latvia. This allowed us to study the impact of mainly natural processes on changes in DOM and its properties.

\section{MATERIALS AND METHODS}

The study site covers the basin of River Salaca in Latvia (Figure 1). The River Salaca basin is located in the northern part of Latvia $\left(3184 \mathrm{~km}^{2}\right)$ and Estonia $\left(237 \mathrm{~km}^{2}\right)$. The length of River Salaca is $95 \mathrm{~km}$. Lake Burtnieks is located within the River Salaca basin and has a surface area of $40.07 \mathrm{~km}^{2}$. It is the fourth largest lake in Latvia, but its basin is largely situated in the territory of the North Vidzeme Biosphere Reserve (established in 1995). Bedrock is covered by Quaternary deposits consisting of moraine material, limnoglacial or fluvioglacial deposits. The climatic conditions can be characterized as humid with a mean annual precipitation of 650-700 mm. The mean temperature in January varies from $-2.6^{\circ} \mathrm{C}$ to $-6.6^{\circ} \mathrm{C}$, and in July from $+16.8^{\circ} \mathrm{C}$ to $+17.6^{\circ} \mathrm{C}$. The tributaries of River Salaca and Lake Burtnieks have mixed 


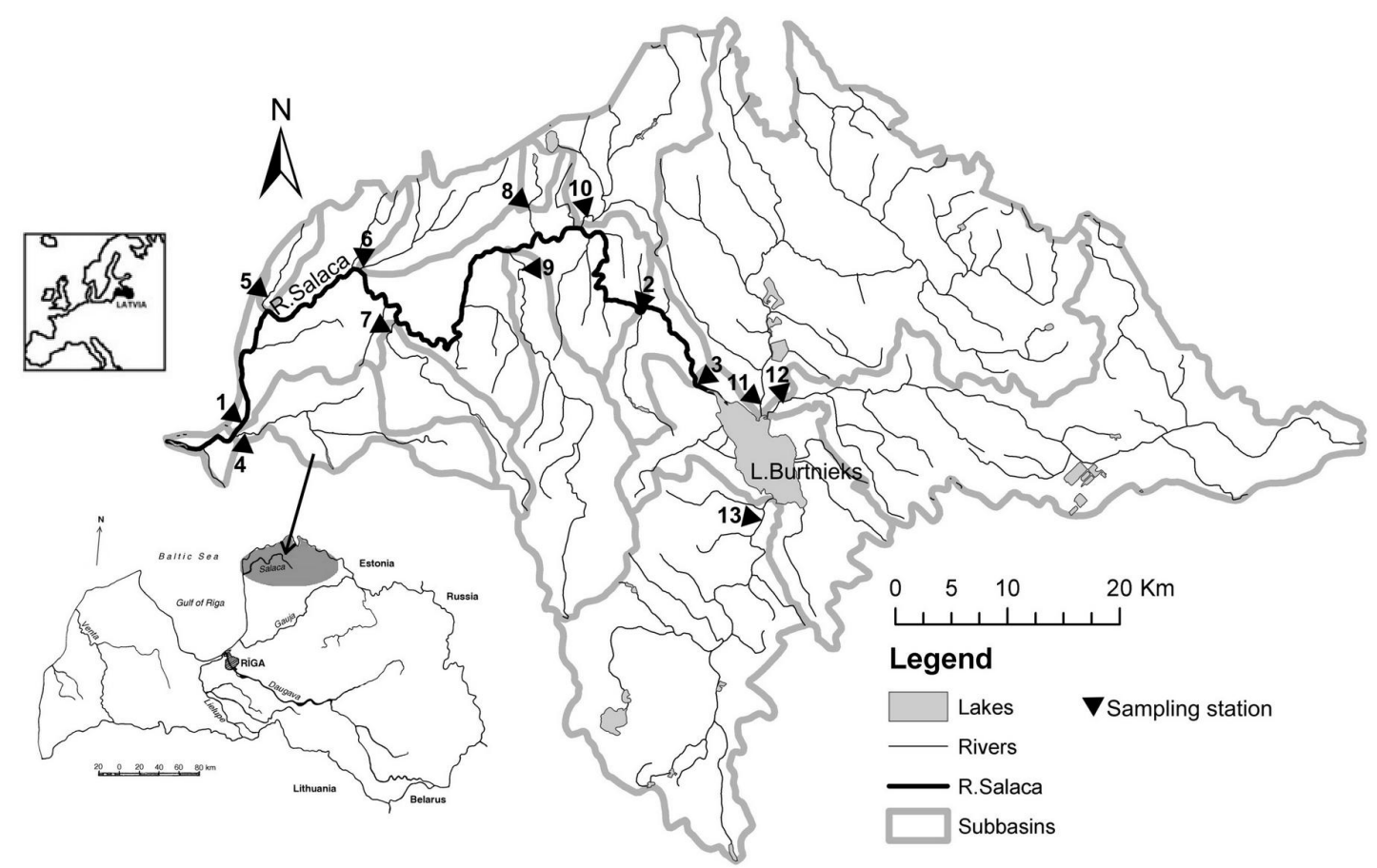

Figure 1

Location of monitoring sites ( $\mathbf{\nabla})$. Number of sampling stations as in Table I.

water feeding: rain, snowmelt and groundwater. The long-term mean annual discharge of the River Salaca is $33.2 \mathrm{~m}^{3} \cdot \mathrm{s}^{-1}$, mean discharge in spring is $49.5 \mathrm{~m}^{3} \cdot \mathrm{s}^{-1}$, in winter $-41.3 \mathrm{~m}^{3} \cdot \mathrm{s}^{-1}$, in autumn $-28.4 \mathrm{~m}^{3} \cdot \mathrm{s}^{-1}$ and in summer $-13.0 \mathrm{~m}^{3} \cdot \mathrm{s}^{-1}$. Extreme discharge in spring reaches up to $264 \mathrm{~m}^{3} \cdot \mathrm{s}^{-1}$, but in that in autumn $-166 \mathrm{~m}^{3} \cdot \mathrm{s}^{-1}$ (Klavins et al., 2002).

Long-term monitoring data on monthly measurements of chemical oxygen demand $(C O D)$, water color and parameters of basic water chemistry at the mouth of the River Salaca were obtained from the Latvian Environment, Geology and Meteorology Centre for the period 1977-2005 (COD for period 1977-2002). River discharge was calculated from daily measurements of water level. Water color was determined colorimetrically until 1995, and was determined spectrophotometrically after 1995 using the Platinum/Cobalt scale. For period 1977-2002 COD was analyzed according to the standard methods used in former USSR. $C O D$ was determined by oxidation with $\mathrm{K}_{2} \mathrm{Cr}_{2} \mathrm{O}_{7}$ and subsequent titration with ferrous ammonium sulfate (Standard methods for chemical analysis of surface waters, 1973). Similar approach can be found in Clesceri et al. (1999; method 5220C).

A detailed survey of the River Salaca basin was carried out from January 2007 until March 2009. Monthly water samples were taken at the sites shown in Figure 1.

The concentration of dissolved oxygen, $\mathrm{pH}$, temperature and conductivity were measured in the field by a HACH HQ40d portable meter. TOC, DOC and total $N$ were measured using a Shimadzu Total Organic Carbon Analyzer TOC $-V_{\mathrm{CSN}}$. Unfiltered samples were used for TOC analysis, all water samples were well shaken before analysis. Samples for $D O C$ analysis were filtered through $0.45 \mu \mathrm{m}$ nylon filters (Whatman GD/X) before analysis. Concentration of particulate organic carbon was expressed as a difference between TOC and DOC. TOC analyser directly measures total carbon and inorganic carbon, but concentrations of TOC are expressed as the difference between total carbon and inorganic carbon. Sample for analysis of total carbon undergoes oxidative combustion $680^{\circ} \mathrm{C}$, but sample of inorganic carbon analysis is acidified with $\mathrm{HCl}$ to $\mathrm{pH} 3$ and as a result $\mathrm{CO}_{2}$ is produced. Concentration of carbon dioxide is detected by non-dispersive infrared (NDIR) gas analyzer. Fresh ultra pure water (Millipore, Direct-Q 3 Water Purification Systems) containing less than 10 ppb TOC were used to prepare standard solutions. Reagent grade potassium hydrogen phthalate and sodium 
hydrogen carbonate was used to prepare standard solutions for total and inorganic carbon, respectively.

The relationship between $C O D$ and $T O C$ was estimated using a calibration experiment which indicated the following relationship between recorded $C O D$ and TOC:

$$
\text { TOC }=(0.2928 \times C O D)+7.9503 \quad r^{2}=0.611, P<0.05,
$$

where: $T O C$ - concentration of total organic carbon, $\mathrm{mg} \mathrm{C} \cdot \mathrm{I}^{-1}$;

$C O D$ - concentration of chemical oxygen demand, $\mathrm{mg} \mathrm{O} \cdot \mathrm{I}^{-1}$.

The calibration between TOC and COD was undertaken for the sampling site Lagaste (mouth of the River Salaca) where the regular monitoring activities were done. To get statistically significant calibration, the measurements were not split into seasonal samples, but pooled. A similar approach has been used in other studies (e.g. Hejzlar et al., 2003; Worrall et al., 2003; Worrall and Burt, 2007; Erlandsson et al., 2008) to calculate DOC or TOC values from historical data of water color and $\mathrm{COD}$ analyzed by oxidation of sample with $\mathrm{KMnO}_{4}$ or $\mathrm{K}_{2} \mathrm{Cr}_{2} \mathrm{O}_{7}\left(C O D_{\mathrm{Mn}}\right.$, and $C O D_{\mathrm{Cr}}$, respectively).

Fluorescence spectra were determined on a Perkin Elmer LS55 spectrofluorometer at room temperature $\left(25^{\circ} \mathrm{C}\right)$. The SSFS (synchronous-scan fluorescence spectroscopy) results were recorded at a speed of $500 \mathrm{~nm} \cdot \mathrm{min}^{-1}$, at a constant offset $(\Delta \lambda=18 \mathrm{~nm})$ between excitation and emission wavelengths. Emission spectra were recorded at a speed of $500 \mathrm{~nm} \cdot \mathrm{min}^{-1}$, excitation of $350 \mathrm{~nm}$. Excitation and emission slit widths were $7 \mathrm{~nm}$.

Fluorescence emission spectra were determined from a wavelength of $380 \mathrm{~nm}$ to $650 \mathrm{~nm}$, and synchronous-scan fluorescence spectra were determined from a wavelength of 250 to $600 \mathrm{~nm}$. At the level of $\mathrm{Ca}^{2+}$ and TOC concentrations common for the River Salaca basin no interferences or impacts of calcium ion presence on fluorescence spectra were observed.

The fluorescence index (FI) developed by McKnight et al. (2001) was used to distinguish sources of aquatic DOM and is a ratio of the emission intensity at a wavelength of $450 \mathrm{~nm}$ to that at $500 \mathrm{~nm}$ at an excitation wavelength of $350 \mathrm{~nm}$ for the River Salaca basin. High indices (in the range $\sim 1.7-2.0$ ) indicate a microbial-derived source. Low indices $(\sim 1.3)$ represent terrestrially derived organic matter.

UV/Vis spectra were recorded on a Thermospectronic Helios $\gamma$ UV (Thermo Electron Co) spectrophotometer in a $1-\mathrm{cm}$ quartz cuvette. $E_{4} / E_{6}$ is absorption ratio at wavelengths 465 to $665 \mathrm{~nm}$ (see supplementary information).

\section{RESULTS AND DISCUSSION}

Organic carbon concentrations in surface waters are influenced by natural and human induced processes. Spatial variability of concentrations of organic matter in the River Salaca basin were comparatively high - TOC concentrations varied from $21-25 \mathrm{mg} \cdot \mathrm{I}^{-1}$ in the waters of Rivers Salaca, Iǵe, and Jogla to $35-40 \mathrm{mg} \cdot \cdot^{-1}$ in Rivers Piǵele, Glāžupe and Melnupe (Table I). The larger proportion of wetlands (Table II) in River Piǵele (83\%) supported higher TOC concentrations in the waters of this river. Agricultural areas within the studied river basin occupy a smaller part than natural areas (forests, wetlands) (Table I). The proportion of arable land comprises about 55\% of the total agricultural land in River Salaca basin and the population density (especially compared with Western European countries) is low, thus it can be supposed that the impact of direct human loading on TOC concentrations was comparatively low and the main source of TOC could be leaching from wetlands and organicrich forest soils.

One very important aspect as to why the River Salaca basin was selected for in-depth study, was the observed increase in water color (concentration of colored dissolved organic substances) during the last few decades (Figure 2) - the brownification of water - a phenomenon known in other European countries and elsewhere (Worrall et al., 2003; Hongve et al., 2004; Roulet and Moore, 2006). It should be mentioned that during the last decade anthropogenic pressure (intensity of agriculture and urban development) was relatively stable and a large part of River Salaca basin has the status of the protected area. 


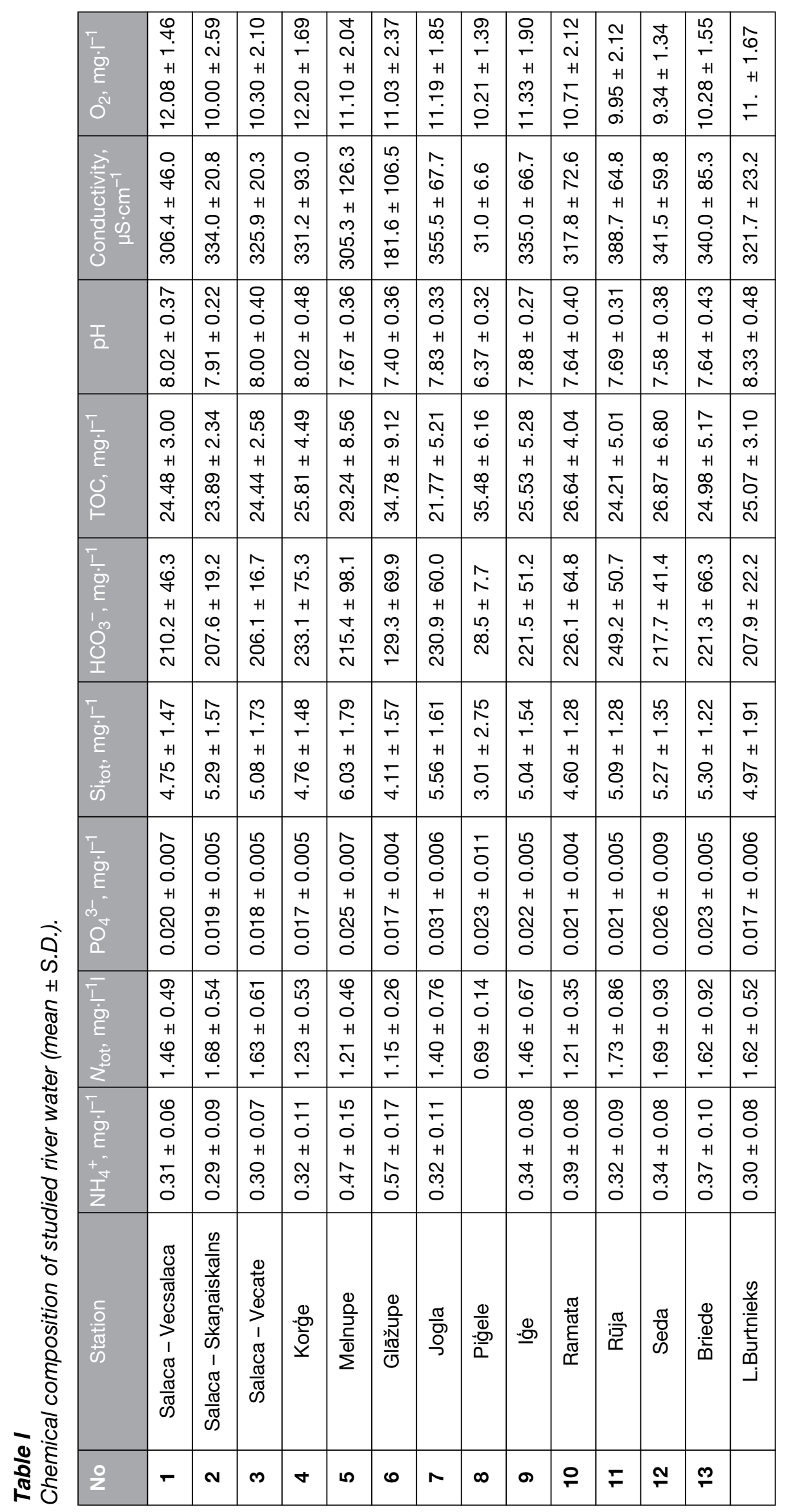




\section{Table II}

Land cover types in the River Salaca basin (CORINE Land Cover 2000 Latvija, 2003).

\begin{tabular}{|c|c|c|c|c|c|c|c|c|}
\hline $\begin{array}{c}\text { No of } \\
\text { sampling } \\
\text { site }^{\text {a }}\end{array}$ & Basin & $\begin{array}{l}\text { Total } \\
\text { area, } \\
\mathrm{km}^{2}\end{array}$ & $\begin{array}{c}\text { Forests } \\
\text { and natural } \\
\text { areas, } \%\end{array}$ & $\begin{array}{l}\text { Arable } \\
\text { land, \% }\end{array}$ & $\begin{array}{c}\text { Other } \\
\text { agric. } \\
\text { land, \% }\end{array}$ & $\begin{array}{c}\text { Bogs, } \\
\%\end{array}$ & $\begin{array}{c}\text { Water, } \\
\%\end{array}$ & $\begin{array}{c}\text { Urban } \\
\text { areas, } \\
\%\end{array}$ \\
\hline 1 & Salaca - Salacgrīva (total) & 3160.17 & 55.94 & 20.98 & 16.80 & 4.01 & 1.89 & 0.38 \\
\hline 2 & Salaca - Skañaiskalns & 2086.19 & 51.61 & 24.30 & 17.72 & 3.23 & 2.71 & 0.43 \\
\hline 3 & Salaca - Vecate & 1984.90 & 52.48 & 23.27 & 17.75 & 3.29 & 2.82 & 0.39 \\
\hline 4 & Korǵe & 104.87 & 64.63 & 20.67 & 11.03 & 3.43 & 0.24 & 0.00 \\
\hline 5 & Melnupe & 19.42 & 75.09 & 14.46 & 5.45 & 5.00 & 0.00 & 0.00 \\
\hline 6 & Glāžupe & 77.16 & 71.66 & 8.75 & 5.84 & 13.52 & 0.00 & 0.23 \\
\hline 7 & Jogla & 78.46 & 63.41 & 12.32 & 21.96 & 1.48 & 0.37 & 0.46 \\
\hline 8 & Piǵele & 16.46 & 14.85 & 0.06 & 0.45 & 83.01 & 1.63 & 0.00 \\
\hline 9 & lǵe & 210.76 & 57.08 & 15.21 & 23.24 & 4.37 & 0.00 & 0.10 \\
\hline 10 & Ramata & 150.42 & 66.88 & 14.31 & 12.99 & 4.40 & 1.42 & 0.00 \\
\hline 11 & Rūja & \begin{tabular}{|l|}
794.69 \\
\end{tabular} & 52.34 & 29.99 & 14.65 & 1.76 & 0.73 & 0.53 \\
\hline 12 & Seda & 539.03 & 57.78 & 16.86 & 20.22 & 3.78 & 0.92 & 0.44 \\
\hline 13 & Briede & 437.04 & 55.51 & 17.09 & 20.20 & 5.50 & 1.51 & 0.19 \\
\hline
\end{tabular}

a Sampling sites as in Figure 1.

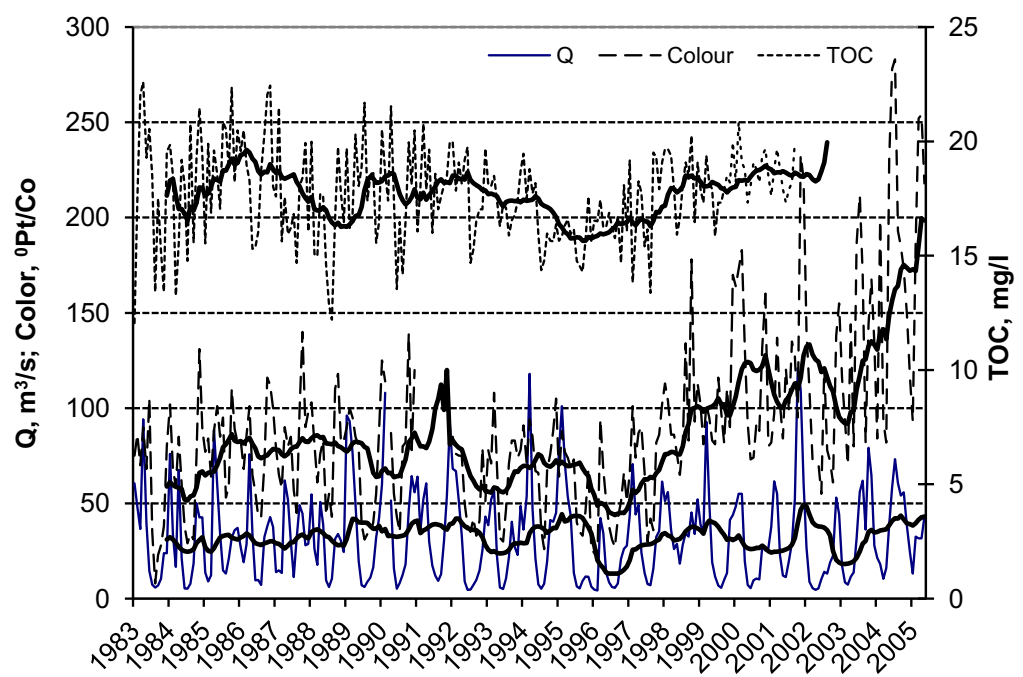

\section{Figure 2}

Long-term (1983-2005) changes of River Salaca discharge, TOC concentrations and water colour in river mouth, station Lagaste (data were smoothed with a 12 months moving average).

To obtain more detailed information on the variability in organic matter concentrations and fluxes, monthly sampling was carried out in the River Salaca basin in 2007 and 2008. Year 2008 was characterized by higher discharges, especially during spring and late autumn (Figure 3). January of 2007 was unusually warm (monthly average air temperature $+0.3^{\circ} \mathrm{C}$ ) and wet. Concentrations of TOC varied between different sampling stations (Table II) and may 


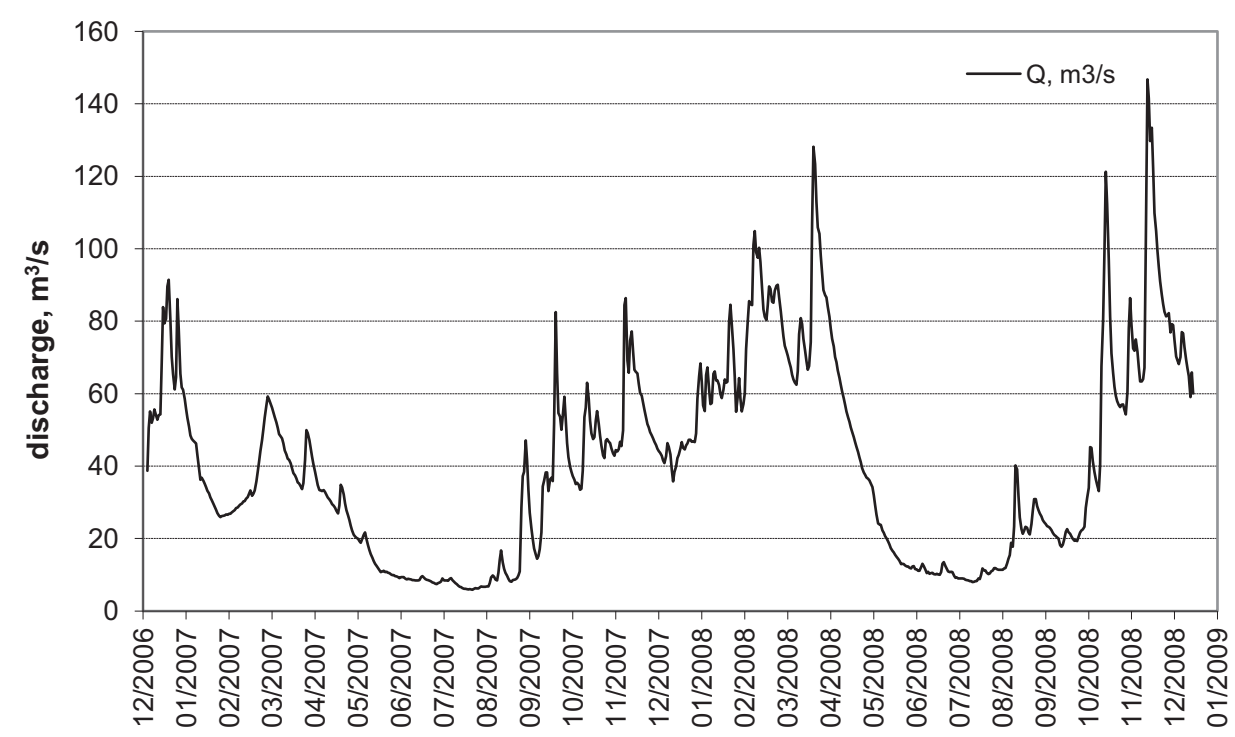

\section{Figure 3}

Daily discharge of the River Salaca at hydrological station Lagaste (river mouth).

have been influenced by land use patterns in the basins. Earlier study (Kokorite et al., 2010) has shown a good correlation $(r=0.59 ; p<0.01)$ between concentrations of chemical oxygen demand and percentage of bogs within the river catchments of Latvia, but other land-use types did not showed statistically significant relationship with $C O D$. The highest concentrations of organic matter were observed in autumn and winter (Figure 4). The highest nutrient concentrations in 2007 were observed in January (total nitrogen was about $3.0 \mathrm{mg} \cdot \mathrm{I}^{-1}$ ) due to leaching from the catchment. Average concentrations of total nitrogen for studied rivers varied from $0.69-1.69 \mathrm{mg} \cdot \mathrm{l}^{-1}$, phosphate concentrations varied from $0.017-0.031 \mathrm{mg} \cdot \mathrm{I}^{-1}$, but conductivity $-31.0-388.0 \mu \mathrm{S} \cdot \mathrm{cm}^{-1}$ (Table II).

The UV-visible spectra of the studied waters (Figure 5) were initially influenced by the presence of humic substances in the DOM pool, however, the spectra were relatively featureless, with a steady increase in absorbance with decreasing wavelength from 800 to $200 \mathrm{~nm}$. A higher intensity of absorption (shoulder in the spectra) at $280 \mathrm{~nm}$ may have been related to the presence of aromatic components in the composition of DOM and the molecular weight of fulvic acids as a major component of the DOM pool (Chin et al., 1994; Chen et al., 2002). In our study the shoulder around $280 \mathrm{~nm}$ was observed in rivers Piǵele and Glāžupe, which have larger proportions of wetlands in their basins (Table I).

To characterize the changes in the properties of DOM, UV absorbance ratios at different wavelengths were used. UV absorbance at $465 \mathrm{~nm}$ ratio vs. absorbance at $665 \mathrm{~nm}\left(E_{4} / E_{6}\right.$ ratio) were used, as suggested by Chen et al. (1977), which are related to the molecular mass of DOM. As seen in Figure 6 , an increase in the $E_{4} / E_{6}$ ratio for all rivers was observed during winter/early autumn when intensive decay of living organic matter took place. For some rivers high $E_{4} / E_{6}$ ratios were observed in early spring (Selberg et al., 2011). Fellman et al. (2009) suggest that the content of labile and biodegradable DOM in water can increase during the high discharge periods in spring and autumn due to faster delivery time of allochtonous DOM from source to river. However, brown-water river Piǵele had low $E_{4} / E_{6}$ ratios during the spring and seasonal variation was low. This indicates on constant inputs of high-molecular organic matter from bog areas. Seasonal differences of DOM quality can be explained by variation of hydrological pathways, land cover types, soil properties between various catchments (e.g., Ågren et al., 2008; Fellman et al., 2009). Other absorbance ratios, like $E_{2} / E_{3}, E_{2} / E_{4}$ reflect presence of aromatic structural units in the DOM or the slope of UV spectra and might be related to input of terrestrial organic matter (Ågren et al., 2008), rich in lignin residues, determining absorption at $254 \mathrm{~nm}$ or $280 \mathrm{~nm}$. Increased presence of lignin residues might be 


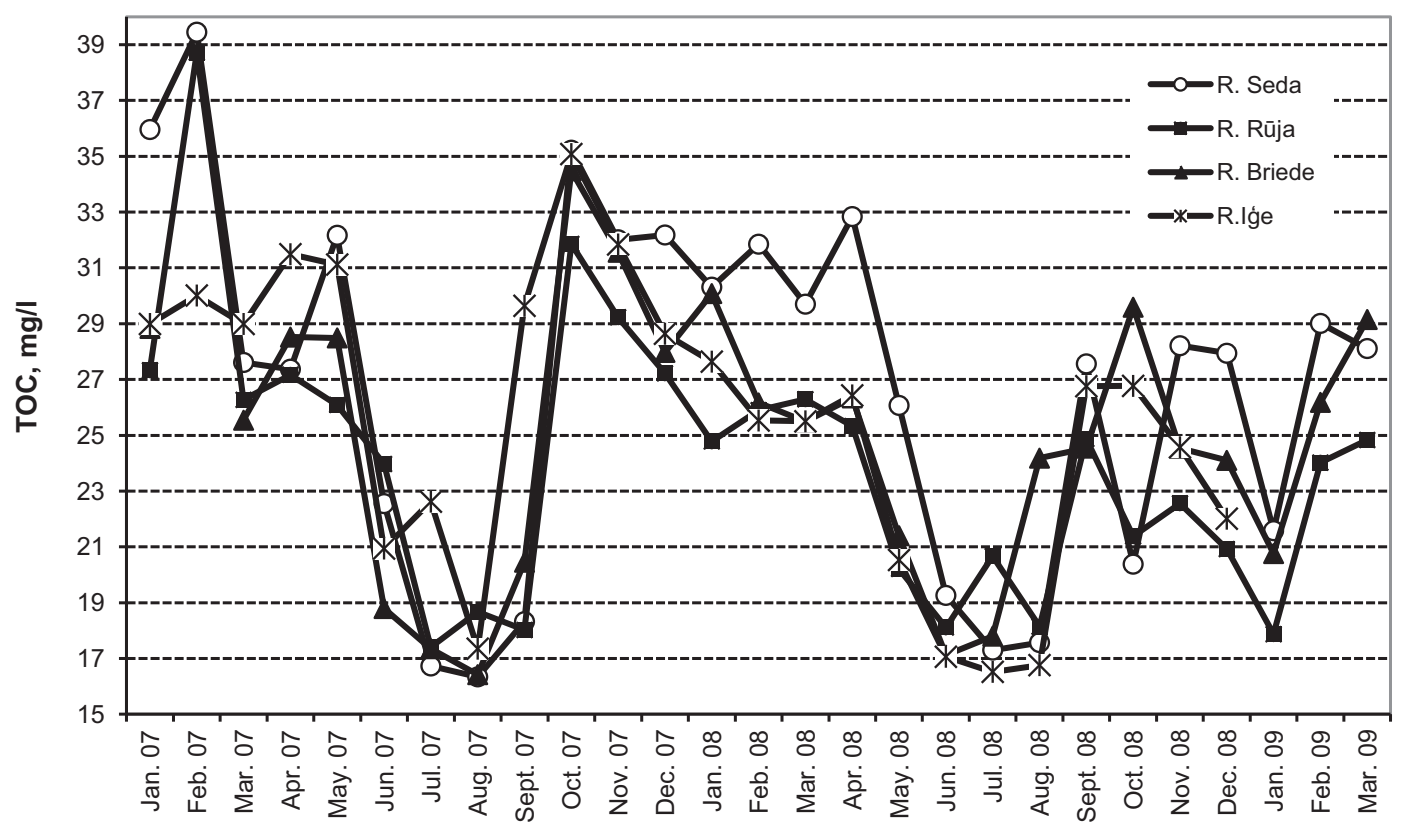

\section{Figure 4}

Variability of TOC concentration (mg. $\mathrm{r}^{-1}$ ) in tributaries of River Salaca and Lake Burtnieks basin (2007-2009).

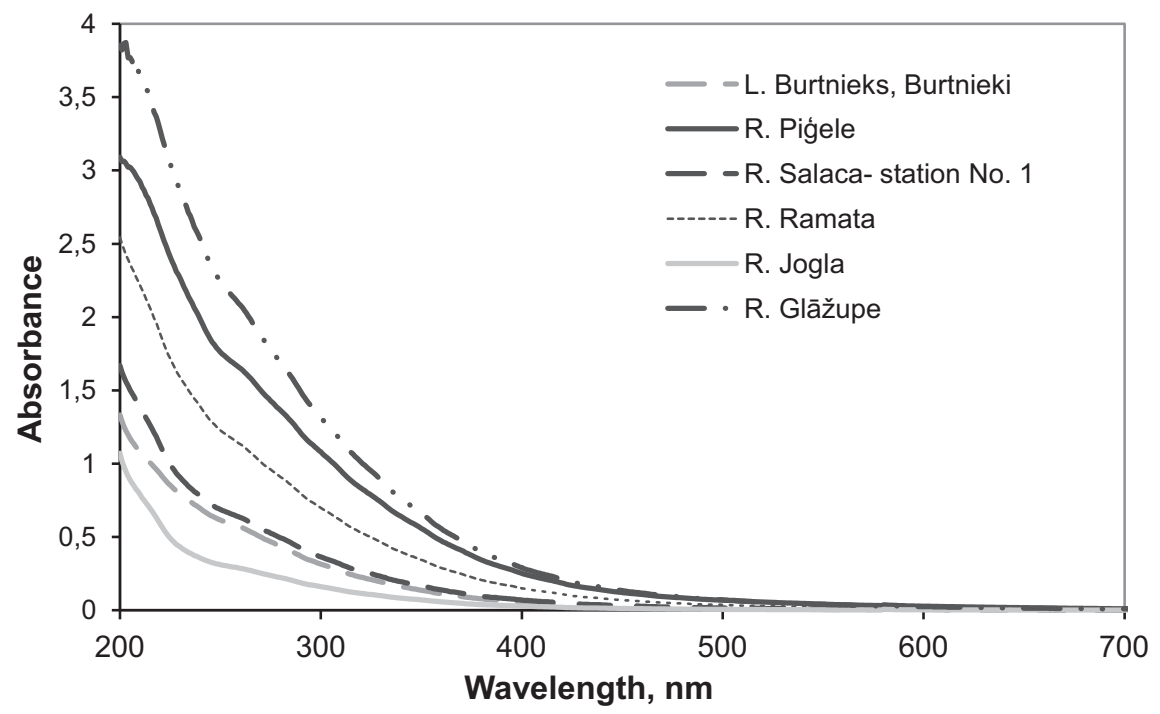

\section{Figure 5}

UV-Vis spectra of waters of River Salaca and its tributaries (September 2007).

related to "fresh" (not decomposed) organic matter, having also higher hydrophobicity (Chen et al., 2002). Observed differences in the seasonal maxims of absorbance ratios thus can be used to illustrate differing sources of DOM inputs in river waters (Figure 6).

Fluorescence spectra has been widely used for characterization of photosynthetic pigments in surface waters (Zsolnay et al., 1999; Ohno, 2002), but they can provide information about natural organic matter (humic and fulvic acids) origin, structure and properties (McKnight et al., 2001). Aquatic humic substances derived from terrestrial plants rich in lignin contain more aromatic and polyaromatic structures (25-35\% of total carbon, as indicated by ${ }^{13} \mathrm{C}$ NMR), than microbial-derived humic substances (less than 15\%), indicating lower aromaticity 

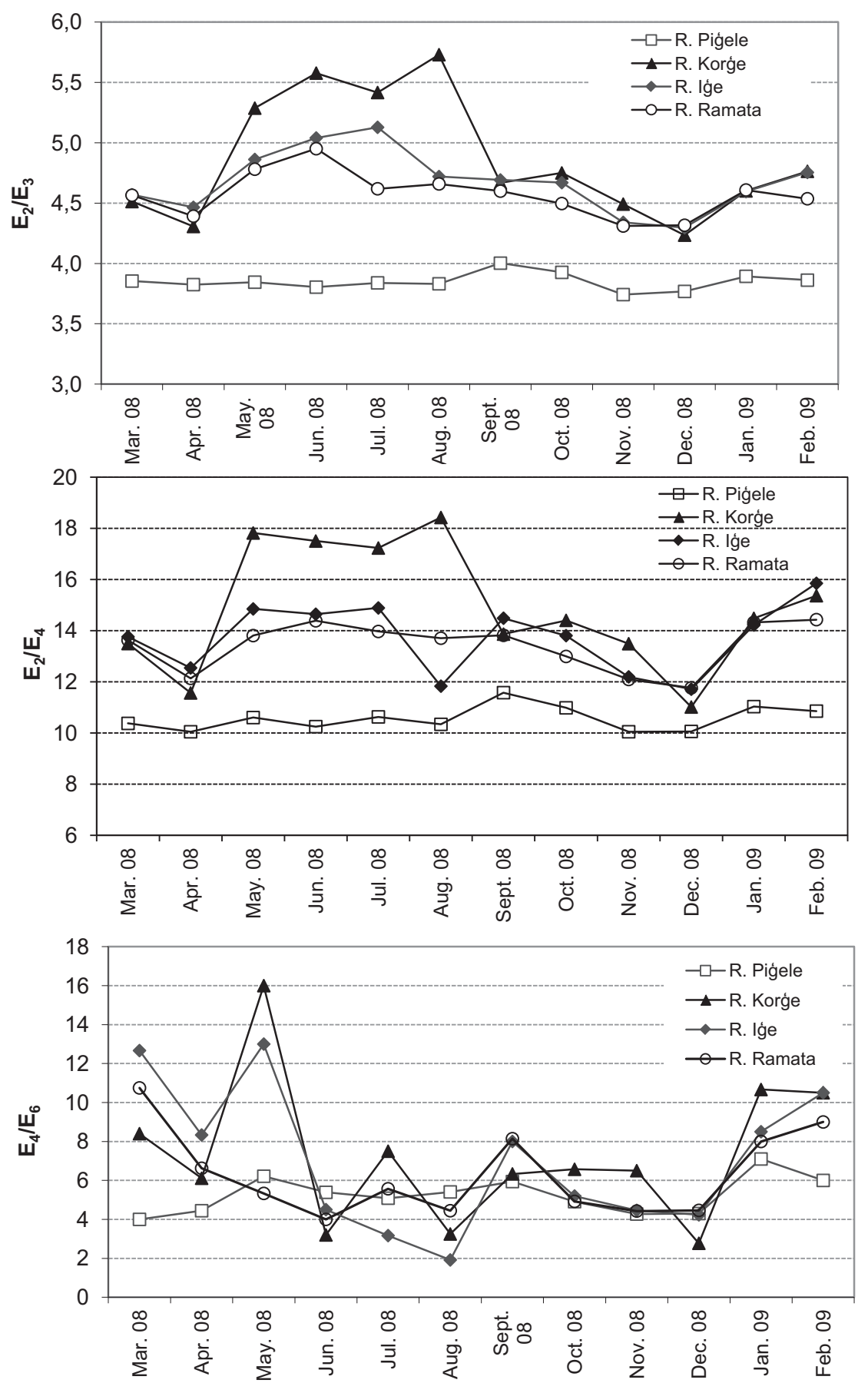

Figure 6

Monthly changes of $E_{2} / E_{3}, E_{2} / E_{4}$ and $E_{4} / E_{6}$ absorbance ratios of the studied water samples from River Salaca basin.

of microbial and algal metabolites and their abundance in cell walls (McKnight et al., 2001). The presence of conjugated aromatic structures and fluorophore structures determine the lower absorption intensity of microbial-derived organic substances in the visible and ultraviolet spectral region. The fluorescence emission spectra at the previously suggested excitation wavelength of the studied waters (Figure 7) have a specific pattern, illustrating presence of humic and fulvic acids and character of spectra differs between seasons 


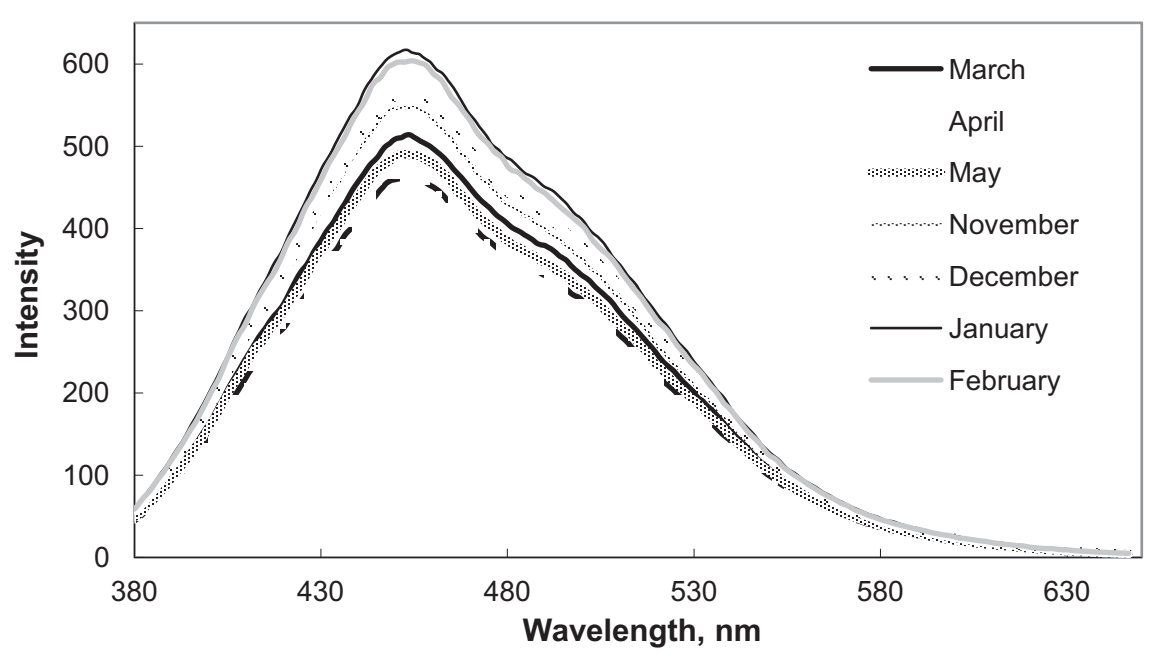

Figure 7

Monthly changes of fluorescence emission spectra of the River Salaca - Skanaiskalns (Ex. $350 \mathrm{~nm}$ ).

(reflecting presence of different processes governing development of DOM composition) and studied rivers. It is known that microbial- and algal-derived DOM has emission maxima between 442 and $448 \mathrm{~nm}$. The spectra of terrestrial-derived DOM have emission maxima at higher wavelengths between 457 and $461 \mathrm{~nm}$ (McKnight et al., 2001).

Fluorescence spectra demonstrated that the properties of DOM vary between seasons (Figure 7). Comparatively low fluorescence intensity was observed in summer, and was higher in winter thus reflecting not only concentration of DOM, but also structural changes (e.g. presence of fluorophores in the structure of DOM). The maximum of the fluorescence spectra in the summer and autumn samples (June-October) was shifted to about $442 \mathrm{~nm}$, but in winter and spring (November-May) the maximum of the fluorescence spectra was $455 \mathrm{~nm}$. It can be supposed that peak emission intensity in DOM samples from River Salaca (at Skañaiskalns) influenced not only microbial and terrestrial sources, but also the decay of algae (abundant in the eutrophic Lake Burtnieks during the summer season) and draining of waters from bogs thus containing peat humic acids.

To distinguish sources of aquatic DOM we used the fluorescence index (FI) developed by McKnight et al. (2001) (a ratio of the emission intensity at a wavelength of $450 \mathrm{~nm}$ to that at $500 \mathrm{~nm}$ ). The FI values in our study for River Salaca, Lake Burtnieks and their tributaries ranged from 1.1 to 1.9 (Figure 8). The character of seasonal changes in FI values was common for all the studied rivers and had a well expressed maximum in summer time, thus indicating the role of primary production and the decay of organic matter in its fluorescent properties. The lowest FI values were observed in highly colored waters with high DOC values (R. Piǵele, R. Glāžupe), draining waters from wetlands (i.e. boreal streams) and these values ranged from 1.1 to 1.4. For these rivers, the seasonal variability in these values was the lowest. Higher FI values were observed in streams in which DOM was of agricultural origin or directly influenced by the intensive eutrophication in Lake Burtnieks - in this case the seasonal variability was higher, and in the summer season the FI values reached 1.8-1.9. The use of the FI thus allowed us to follow the changes in organic matter composition and the FI values were related to processes in the water body basin and sources of DOM. Our study indicates that the ratio of emission intensity at 450-500 nm was $\sim 1.9$ not only for microbial-derived samples but also for DOM common in eutrophic water bodies and with algal origin. A low ratio of emission intensity $\sim 1.4$ (and lower) was common not only for terrestrial-derived samples, but also for samples of draining waters from peatlands. The trends of changes of FI reflects a different dimension of DOM pool properties and factors affecting seasonal and spatial changes and 

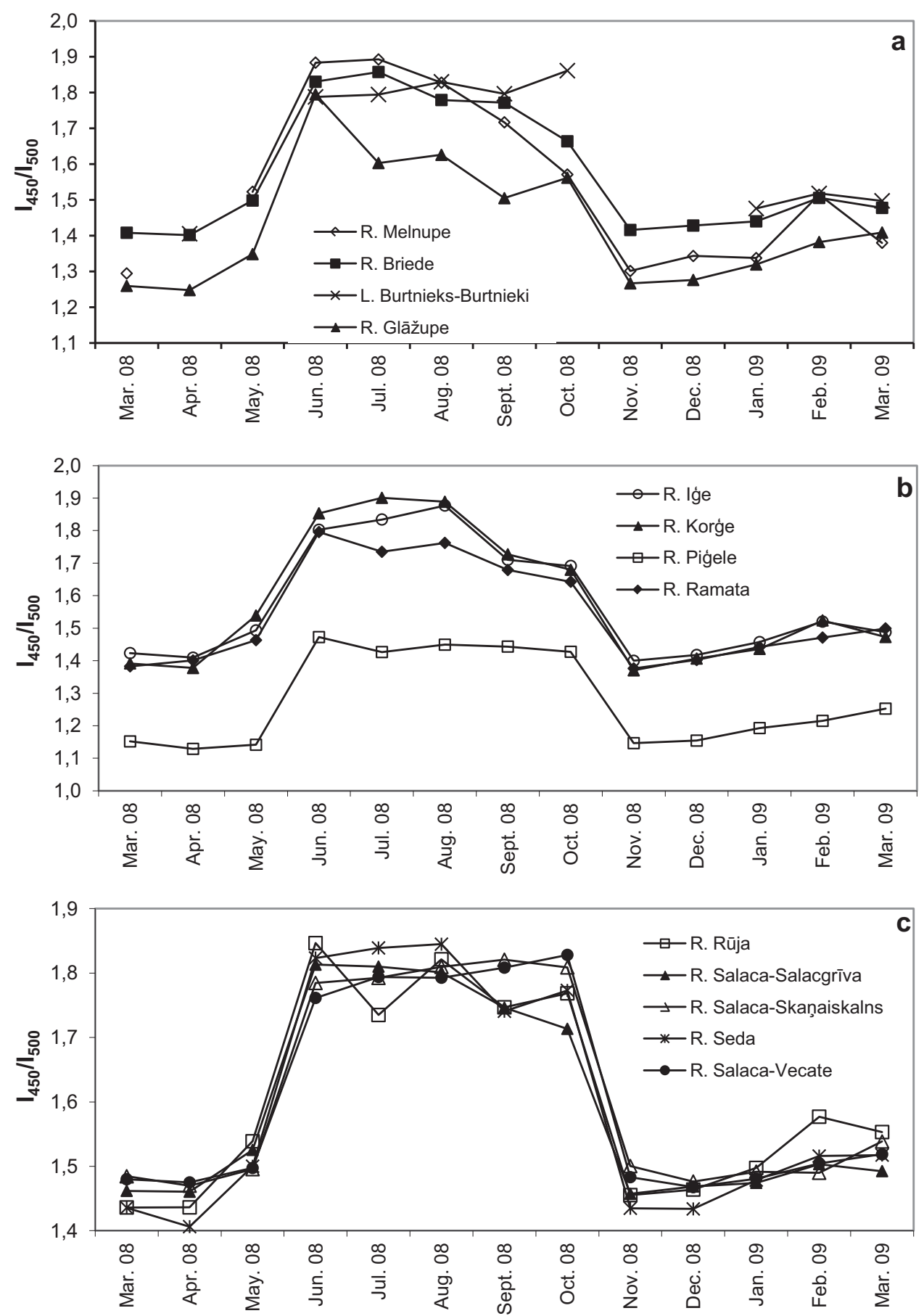

Figure 8

Monthly changes of $I_{450 / 500}(E x .370 \mathrm{~nm})$ of the studied water samples from River Salaca basin.

enables use of this parameter for studies of DOM precursor material and aromaticity (McKnight et al., 2001).

Synchronous scan fluorescence spectrometry (SSFS) is more informative than excitation emission spectra and was applied to characterize DOM in the studied water samples. Fluorescence intensities of the spectral region around $280-298 \mathrm{~nm}$ were assigned mainly to aromatic amino acids and some other volatile acids containing highly conjugated aliphatic 

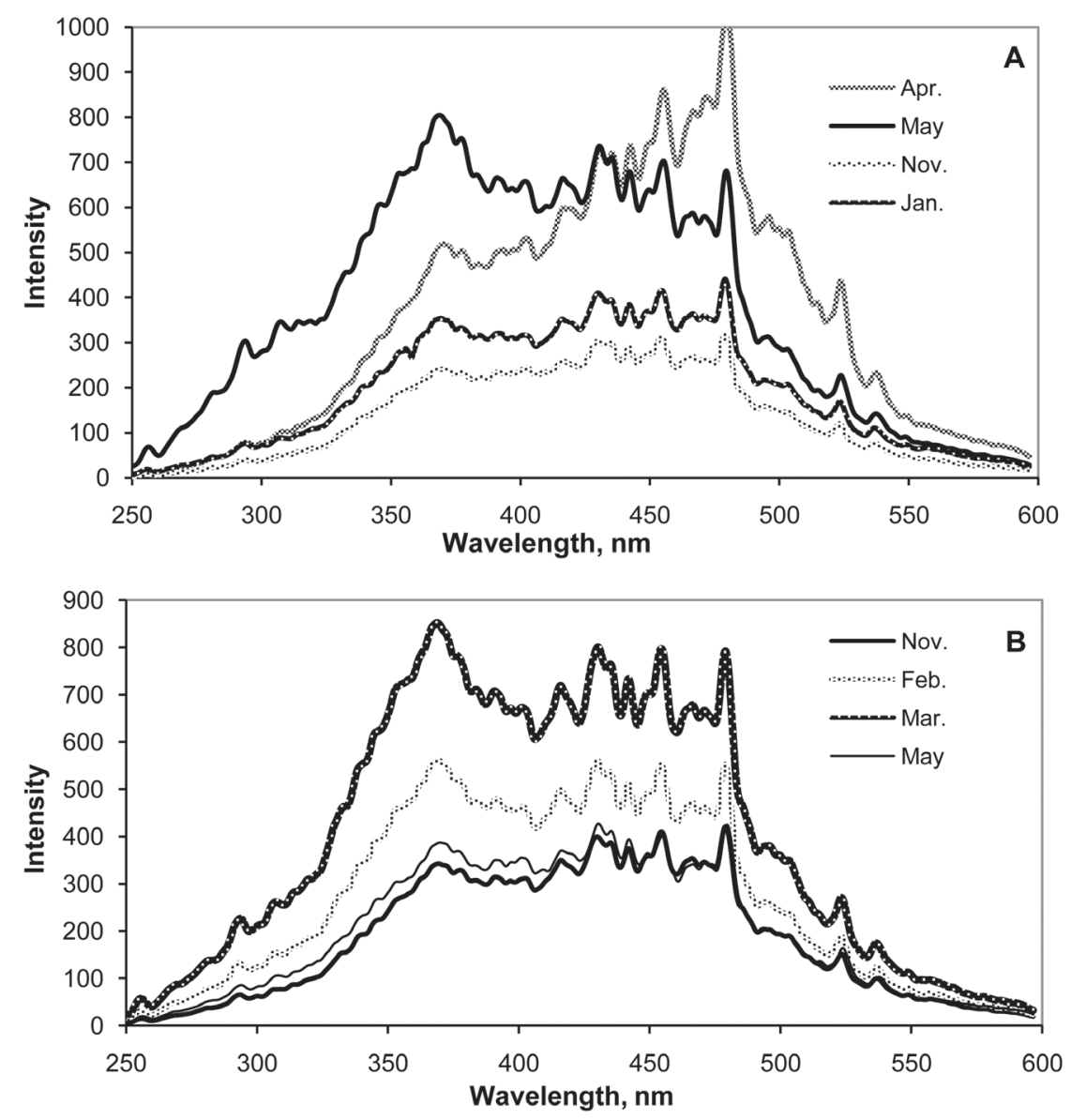

\section{Figure 9}

Monthly changes in the fluorescence synchronous scan spectra of river Korǵe (A) and Salaca at sampling station near Salacgriva (B).

structures (Peuravuori et al., 2002). The fluorescence spectra of river Korǵe (Figure 9a) demonstrated that the highest fluorescence intensity around 280-298 nm was in May (after a flood period when intensive surplus of terrestrial DOM dominated) and was considerably lower in other months. However, the SSFS results for River Salaca (Figure 9b) showed that the content of aromatic amino acids and other volatile acids with highly conjugated aliphatic structures was higher in February and March when intensive decay of organic matter during ice cover took place.

Fluorescence intensities within the SSF spectral region around 330-348 nm could have been due to naphthalene and its derivatives, but such structures were not very common in DOM of the studied water samples. Fluorescence intensity was higher in the spectral range around 355-373 nm, indicating the presence of polycyclic aromatics with three to four fused benzene rings, but the signal was lower at around $400-418 \mathrm{~nm}$, which corresponds to polycyclic aromatics with approximately five fused benzene rings (Peuravuori et al., 2002).

Important spectral range for studied waters was around $460-478 \mathrm{~nm}$, and probably reflected the influence of lignin descriptors fluorescence within this region (Peuravuori et al., 2002). Significant changes were observed in April and May. There was a higher content of polycyclic aromatics with three to four fused benzene rings in May compared with that in April, but the content of possible lignin structure descriptors increased in April, but decreased in May (Figure 9). 


\section{CONCLUSIONS}

The waters of River Salaca are characterized by low anthropogenic pressure, however, the concentrations of total organic carbon in waters of the river and its tributaries are high and the water color during the last few decades has increased. As tools to study the composition of dissolved organic substances in the waters of River Salaca and its tributaries, the use of UV and fluorescence spectroscopy was evaluated. The use of the fluorescence index (a ratio of the emission intensity at a wavelength of $450 \mathrm{~nm}$ to that at $500 \mathrm{~nm}$ ) allowed us to distinguish sources of aquatic dissolved organic matter, characterize processes in the water body basin and to follow changes in organic matter composition. Synchronous scan fluorescence spectrometry is more informative than excitation emission spectra and provides information on the basic structural features of dissolved organic matter.

\section{ACKNOWLEDGEMENTS}

This research was supported by National Research Program "Climate Change Impact on Water Environment in Latvia" and European Social Fund (grant No.: 2009/0214/1DP/1.1.1.2.0/09/APIA/VIAA/089).

\section{REFERENCES}

Ågren A., Buffam I., Berggren M., Bishop K., Jansson M. and Laudon H., 2008. Dissolved organic carbon characteristics in boreal streams in a forest-wetland gradient during the transition between winter and summer. J. Geophys. Res., 113, G03031.

Arvola L., Räike A., Kortelainen P. and Järvinen M., 2004. The effect of climate and landuse on TOC concentrations and loads in Finnish rivers. Boreal Environ. Res., 9, 381-387.

Baker A., Tipping E., Thacker S.A. and Gondar D., 2008. Relating dissolved organic matter fluorescence and functional properties. Chemosphere, 73, 1765-1772.

Chen Y., Senesi N. and Schnitzer M., 1977. Information provided on humic substances by $E_{4} / E_{6}$ ratios. Soil Sci. Soc. Am. J., 41, 352-358.

Chen J., Gu B., LeBoeuf E.J., Pan H. and Dai S., 2002. Spectroscopic characterization of the structural and functional properties of natural organic matter fractions. Chemosphere, 48, 59-68.

Chin Y., Aiken G.R. and O'Loughlin E., 1994. Molecular weight, polydispersity and spectroscopic properties of aquatic humic substances. Environ. Sci. Technol., 28, 1853-1858.

Clair T.A., Dennis I.F., Vet R. and Laudon H., 2008. Long-term trends in catchment organic carbon and nitrogen exports from three acidified catchments in Nova Scotia, Canada. Biogeochemistry, 87, 83-97.

Clesceri L.S., Greenberg A.E., Eaton A.D. (Eds.), 1999. Standard Methods for the Examination of Water and Wastewater, 20th edition, American Public Health Association, Washington DC.

CORINE Land Cover 2000 Latvija, 2003. Latvijas Vides aǵentūra, Eiropas Vides aǵentūra (scale 1:100000).

de Lange H.J., Morris D.P. and Williamson C.E., 2003. Solar ultraviolet photodegradation of DOC may stimulate freshwater food webs. J. Plankt. Res., 25, 111-117.

Depetris P.J. and Kempe S., 1993. Carbon dynamics and sources in the Parana River. Limnol. Oceanogr., 38, 382-395.

Erlandsson M., Buffam I., Fölster J., Laudon H., Temnerud J., Weyhenmeyer G.A. and Bishop K., 2008. Thirty-five years of synchrony in the organic matter concentrations of Swedish rivers explained by variation in flow and sulphate. Glob. Chang. Biol., 14, 1-8.

Evans C.D., Monteith D.T. and Cooper D.M., 2005. Long-term increases in surface water dissolved organic carbon: observations, possible causes and environmental impacts. Environ. Pollut., 137, 55-71.

Fellman J.B., Hood E., D'Amore D.V., Edwards R.T. and White D., 2009. Seasonal changes in the chemical quality and biodegradability of dissolved organic matter exported from soils to streams in coastal temperate rainforest watersheds. Biogeochemistry, 95, 277-293. 
Gergel S.E., Turner M.G. and Kratz T.K., 1999. Dissolved organic carbon as an indicator of the scale of watershed influence on lakes and rivers. Ecol. Appl., 9, 1377-1390.

Hejzlar J., Dubrovsky M., Buchtele J. and Ružička M., 2003. The apparent and potential effects of climate change on the inferred concentration of dissolved organic matter in a Sci. Total Environ., 310, 143-152.

Hongve D., Riise G. and Kristiansen J.F., 2004. Increased colour and organic acid concentrations in Norwegian forest lakes and drinking water - a result of increased precipitation? Aquat. Sci., 66, 231-238.

Kelton N., Molot L.A. and Dillon P.J., 2007. Spectrofuorimetric properties of dissolved organic matter from Central and Southern Ontario streams and the influence of iron and irradiation. Water Res., 41, 638-646.

Klavins M., Rodinovs V. and Kokorite I., 2002. Chemistry of surface waters in Latvia. Riga, LU.

Kokorite I., Klavins M. and Rodinov V., 2010. Impact of catchment properties on aquatic chemistry in the river of Latvia. Hydrol. Res., 41, 320-329.

McKnight D., Boyer E.W., Westerhoff P.K., Doran P.T., Kulbe T. and Andersen D.T., 2001. Spectrofluorimetric characterization of dissolved organic matter for identification of precursor organic material and aromaticity. Limnol. Oceanogr., 46, 38-48.

Neff J.C. and Asner G.P., 2001. Dissolved organic carbon in terrestrial ecosystems: synthesis and a model. Ecosystems, 4, 29-48.

Ohno T., 2002. Fluorescence inner-filtering correction for determining the humification index of dissolved organic matter. Environ. Sci. Technol., 36, 742-746.

Pettine M., Patrolecco L., Camusso M. and Crescenzio S., 1998. Transport of carbon and nitrogen to the Northern Adriatic Sea by the Po River. Estuar. Coast. Shelf S., 46, 127-142.

Peuravuori J., Koivikko R. and Pihlaja K., 2002. Characterization, differentiation and classification of aquatic humic matter separated with different sobents: synchronous scanning fluorescence spectroscopy. Water Res., 36, 4552-4562.

Roulet N. and Moore T.R., 2006. Browning the waters. Nature, 414, 283-284.

Selberg A., Viik M., Ehapalu K. and Tenno T., 2011. Content and composition of natural organic matter in water of Lake Pitkajärv and mire feeding Kuke River (Estonia). J. Hydrol., 400, 274-280.

Standard methods for chemical analysis of surface waters, 1973. Leningrad: Gidromeoizdat (in Russian).

Vuorenmaa J., Forsius M. and Mannio J., 2006. Increasing trends of total organic carbon concentrations in small forest lakes in Finland from 1987 to 2003. Sci. Total Environ., 365, 47-65.

Westerhoff P. and Anning D., 2000. Concentrations and characteristics of organic carbon in surface water in Arizona: influence of urbanization. J. Hydrol., 236, 202-222.

Worrall F. and Burt T.P., 2007. Trends in DOC concentration in Great Britain. J. Hydrol., 346, 81-92.

Worrall F., Burt T. and Shedden R., 2003. Long term records of riverine dissolved organic matter. Biogeochemistry, 64, 165-178.

Wu F.C., Kothawala D.N., Evans R.D., Dillon P.J. and Cai Y.R., 2007. Relationship between DOC concentration, molecular size and fluorescence properties of DOM in a stream. Appl. Geochem., 22, 1659-1667.

Zsolnay A., Baigar E., Jimenez M., Steinweg B. and Saccomandi F., 1999. Differentiating with fluorescence spectroscopy the sources of dissolved organic matter in soils subjected to drying. Chemosphere, 38, 45-50. 